psychologii politycznej, skupionymi na pytaniach, w jaki sposób i w jakim stopniu jednostka musi być ograniczana w swych relacjach społecznych.

PRZE七OŻYŁ M A R I N P O LA K OW S K I

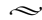

I

MARCIN POLAKOWSKI

Wydział Humanistyczny UMK

\title{
Polityk jako terapeuta
}

W

ydarzenia lat 60. w Ameryce wywołały reakcję nie tylko wśród amerykańskich elit politycznych. Przemiana kultury i obyczajów społeczeństwa amerykańskiego musiała zainteresować także badaczy społecznych. Owocem tego zainteresowania były przede wszystkim poszukiwania intelektualnych źródeł wydarzeń lat 60 . na różnych poziomach analizy, identyfikowanych zazwyczaj z rozmaitymi nurtami marksizmu, egzystencjalizmu czy freudyzmu.

Zainteresowanie Freudem, a zwłaszcza charakterem, siłą oddziaływania i implikacjami jego myśli społecznej, nie zaczęło się jednak w latach 60 . Jednym $\mathrm{z}$ wielu badaczy, którzy podjelli temat freudyzmu w wymiarze społeczno-politycznym już wcześniej, był Philip Rieff. Celem niniejszego szkicu jest przybliżenie postaci tego zupełnie nieznanego w Polsce, a i nieco zapomnianego w świecie anglojęzycznym myśliciela oraz zasygnalizowanie ważniejszych wątków jego interpretacji współczesnych przemian kultury, społeczeństwa i polityki.

\section{Philip Rieff - przedstawienie postaci}

Philip Rieff urodził się w grudniu 1922 roku, w rok po tym, jak jego rodzice - niezamożni, religijni żydowscy imigranci - przybyli z Litwy do Ameryki i zamieszkali w Chicago ${ }^{2}$. Choć jego rodziców nie było stać na ponoszenie kosztów edukacji wyższej, młody Philip, wyróżniając się zapałem

Niezwykle wpływową pracą inspirowaną Freudem był, jak doskonale wiadomo, Eros i cywilizacja Marcusego. Zob. H. Marcuse, Eros i cywilizacja, przeł. H. Jankowska, A. Pawelski, Warszawa 1998.

Podając podstawowe informacje dotyczące życia Rieffa, opieram się na: A. A. W. Zondervan, Sociology and the Sacred: An Introduction to Philip Rieffs Theory of Culture, TorontoBuffalo-London 2005, zwłaszcza s. 12-24. Książka ta jest zresztą ogólnym i podstawowym omówieniem teorii Rieffa. 
i talentem do nauki, został objęty programem dla uzdolnionej młodzieży i otrzymał stypendium umożliwiające mu podjęcie studiów na Uniwersytecie w Chicago. Studia przerwane przez wojnę, w czasie której pełnił służbę w lotnictwie, Rieff ukończył, broniąc pracę magisterską poświęconą myśli Samuela T. Coleridge'a i napisaną pod kierunkiem Edwarda Shilsa. Rieff w młodości, jak większość jego rówieśników, był żywo zainteresowany myślą marksistowską, z czasem jednak zaczął skłaniać się ku dziedzictwu Freuda, które stopniowo zdobywało sobie coraz większą popularność w życiu intelektualnym Ameryki. O ile jednak koncepcje twórcy psychoanalizy były analizowane przez pryzmat jego teorii dotyczących życia psychicznego człowieka lub w mniejszym stopniu społecznego wymiaru interpretacji religii czy obyczajów, o tyle spotykały się ze stosunkowo niewielkim odzewem w obszarze ich konsekwencji politycznych. Rieff właśnie wątkom filozoficznopolitycznym w spuściznie austriackiego myśliciela poświęcił swój doktorat, obroniony w 1954 roku na Wydziale Nauk Politycznych w Chicago. Praca ta, w znacznym stopniu poprawiona, została wydana pięć lat później jako pierwsza książka Rieffa zatytułowana Freud: The Mind of the Moralist. Swe zainteresowanie freudyzmem, tym razem interpretowanym głównie przez pryzmat twórców inspirowanych psychoanalizą, takich jak Carl G. Jung, Wilhelm Reich czy David H. Lawrence, amerykański badacz kontynuował przede wszystkim w studium The Triumph of the Therapeutic (1966). Wracał także do niego w kolejnych pracach: Fellow Teachers (1973), The Feeling Intellect: Selected Writings (1990) czy - wydanych pośmiertnie - Charisma: The Gift of Grace, and How It Has Been Taken Away from Us (2007) oraz trzech częściach Sacred Order/Social Order $(2006,2007,2008)$, mających być w założeniu podsumowaniem jego pracy i dziełem życia.

Lata 70., co widać po nie najbogatszym dorobku prac Rieffa, stanowily niezwykle ważną cezurę w jego życiu oraz pracy naukowej. Wcześniej skupiony na pracy skrupulatnego badacza pism Freuda i kulturowego wpływu freudyzmu, próbujący realizować misję naukowca poszukującego obiektywnego opisu zjawisk kulturowych i społecznych, Rieff popada w rezygnację charakteryzującą się w zasadzie zaprzestaniem publikowania - poza okazjonalnymi artykułami - rozpraw naukowych oraz jawnym porzuceniem poprzedniego paradygmatu badawczego. Autor The Triumph of the Therapeutic po wydarzeniach lat 60 . i rewolucji kulturowej stwierdza, że w ramach teorii kultury, ku której jego zainteresowania stopniowo ewoluowały, nie może być mowy o próbie poszukiwania neutralnego punktu widzenia. Zmianę tę widać doskonale $\mathrm{w}$ formie kolejnych prac Rieffa, przybierających w coraz większym stopniu kształt luźnych, nieuporządkowanych rozważań, okraszanych efektownymi porównaniami, uwagami czy nawet anegdotami. 
Między innymi z tych właśnie powodów zmarły w 2006 roku i nieco zapomniany przez lata Rieff, coraz bardziej ograniczający swą aktywność wraz z upływem dekad i prowadzący życie wykładowcy uniwersytetów Brandeis, Harvarda, Berkeley, Monachium czy Pensylwanii, nigdy nie ukończył swego trzyczęściowego opus magnum. Pozostał znany głównie z koncepcji wyłożonych w swoich dwóch pierwszych pracach. Na kwestiach w nich przedstawionych skupimy się poniżej.

\section{Freud i kultura}

Interpretacja Freuda przedstawiona w tekstach amerykańskiego badacza skupia się przede wszystkim na wątkach mogących mieć poważne implikacje w wymiarze społecznym, politycznym czy, jak z czasem zaczął wyrażać się Rieff, kulturowym. Analizie prac Freuda przedstawionej we Freud: The Mind of the Moralist towarzyszy więc próba przedstawienia wpływu psychoanalizy oraz wynikających z niej pojęć i ocen procesów społecznych na życie współczesnych społeczeństw zachodnich. Wpływ ten zostaje ujęty przez Rieffa w formie dojrzałego opisu w książce The Triumph of the Therapeutic przy okazji analizy kolejnych dzieł pisarzy współczesnych, inspirowanych dziełem Freuda. To właśnie koncepcja poszerzającej swe wpływy w świecie zachodnim postawy terapeutycznej pozostaje najbardziej znanym wątkiem pism Rieffa.

Tradycyjne formy kultury kształtowały relacje między jednostką a wspólnotą poprzez ekwiwalentny zbiór zakazów i zwolnień z tych zakazów, przyjmowanych w ramach zawierzenia elitom kulturowym, w celu dążenia do ideałów zawartych w każdej kulturze. Roszczenia moralne ukryte w kulturze kształtowały określone dyspozycje ludzkiego charakteru. Jednostka, poddając się utrwalonym kanonom moralnym, dokonywała aktu zawierzenia, jednocześnie przyjmując określony i skończony zasób celów działania i sposobów ich osiągnięcia .

W tradycyjnych, przednowożytnych formach kultury - jak utrzymuje Rieff - zadanie autorytetu polegało więc na mediowaniu pomiędzy aspiracjami jednostki a celami życia wspólnotowego. Tego typu mediacja nie tylko pozwalała uniknąć poczucia pustki i bezsensowności świata, prowadzącego do rozpadu wspólnoty, lecz stanowiła fundamentalny przejaw zawierzenia

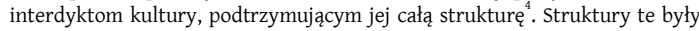
ustanawiane i podtrzymywane przez proroków narzucających określony

C. Lasch, Bunt elit, przeł. D. Rodziewicz, Kraków 1997, s. 216-217.

Rieff w swych radach sam zwykł raczej zakazywać, niż dawać wskazówki. Jak się wyraził: „stworzenie przeciwstawnych... ideałów, wojujących prawd, to położenie pieczęci na przerażającej zdolności człowieka do wyrażania wszystkiego". Cyt. za: tamże, s. 217. 
model i obwarowujący go sankcją absolutną ${ }^{5}$. Religijny charakter instytucji kulturowych miał za zadanie porządkować unikalne doświadczenia egzystencjalne człowieka, dokonywać transliteracji niezmiennego porządku świętego w jego widzialną modalność - partykularny, podległy konwencji i okolicznościom porządek społeczny ${ }^{6}$.

Ten tradycyjny wymiar kultury z całą mocą został zanegowany w myśli Freuda. Analizując dzieło Freuda i jego implikacje, Rieff przekonuje, że austriacki badacz jako pierwszy w dziejach położył fundamenty pod niespotykany wcześniej konflikt każdego autorytetu we wspólnocie z emocjami i impulsami wewnętrznymi człowieka. Kultura w teorii Freuda ma charakter niezbywalnie autorytarny i dlatego też w imię celów wspólnotowych ogranicza ekspresję jednostki.

Rieff wskazuje, że teoria kultury Freuda to niezwykle przenikliwa analiza człowieka i miejsca, jakie zajmuje on w porządku zbiorowym. Narzędzia teoretyczne stworzone przez Freuda po raz pierwszy dały człowiekowi możliwość tak daleko posuniętej analizy, skierowanej zarówno w stronę diagnozy stosunków społecznych, jak i w kierunku jego wewnętrznych doznań ${ }^{7}$.

Freud w interpretacji amerykańskiego myśliciela zgodnie z tradycyjną wizją kultury wskazuje na rolę ograniczeń w kształtowaniu ludzkiego charakteru i przystosowywaniu go do materii życia grupowego. Owe ograniczenia na drodze sublimacji dławią naturalne ludzkie instynkty, by umożliwić mu współżycie z innymi. Sublimacja jest konieczna, gdyż stan pełnego wyzwolenia impulsów jest groźny dla każdej kultury oraz społeczności. Z tego powodu, kooperacja w zbiorowości rodzi konieczność sublimacji i powstrzymywania jednostki przed uwolnieniem jej pragnień ${ }^{8}$.

Człowiek w wizji Freuda znajduje się więc w sytuacji tragicznej, w której na jego barki nakładane są nierzeczywiste struktury kultury, wcielone zwłaszcza w mechanizmy wiary religijnej, które prowadzą człowieka do neuroz, lecz umożliwiają mu zarazem współżycie w grupie. U Freuda silnie romantyczne dowartościowanie autonomii i swobodnej ekspresji jednostki łączy się jednak ze zgoła pozytywistyczną, choć pełną zwątpień, wiarą w reformatorskie możliwości nauki. Psychoanaliza i techniki terapeutyczne miałyby stanowić więc próbę załagodzenia niekorzystnej sytuacji człowieka, umożliwiając mu uświadomienie sobie własnych dążeń i ograniczeń oraz podsuwając mu narzędzia prowadzące do ich opanowania. „Neurotyk, który

P. Rieff, The Triumph of the Therapeutic: Uses of Faith after Freud, Chicago-London 1987, s. 232233.

6 Tenże, Sacred Order/Social Order, Vol. I: My Life Among the Deathworks. Illustrations of the Aesthetics of Authority, Charlottesville-London 2006, s. 2.

Tenże, Freud: The Mind of the Moralist, Chicago-London 1979, s. 358.

Tamże, s. 360-363. 
staje się psychoanalitykiem pokonuje swą własną niedolę i ma możliwość pomocy innym" ". Przesunięcie dokonane przez Freuda dowartościowuje więc jednostkę kosztem wspólnoty, zaś za główne miejsce, gdzie ścierają się impulsy grupowe i indywidualne, uznaje ludzką psychikę. Z pozoru więc niewspólnotowe problemy, takie jak kwestia uwolnienia energii libidalnej i umożliwienia jednostce ekspresji, mają wymiar jak najbardziej społeczny.

Terapia w ujęciu Rieffa, niekoniecznie zgodnie z intencjami ojca psychoanalizy ${ }^{10}$, uzyskała szczególny status we współczesnych wspólnotach. Terapia zdezawuowała bowiem wszelkie zakazy obecne w ramach tradycyjnych kultur, stawiając nacisk nie na zakazy, lecz na zwolnienia od tych zakazów, mające zredukować niebezpieczeństwo neuroz oraz zapewnić jednostce swobodną ekspresję. Dyskredytacja wszelkiej formy autorytetu sprawiła, iż współczesna kultura znalazła się w kryzysie.

Procesy będące przejawem tego kryzysu charakteryzują się przede wszystkim negacją wartości religii, uważanej nie za konstytutywny element istnienia i porządku wspólnoty, lecz mającej być strukturą hegemoniczną, prowadzącą do opersji i ograniczenia ludzkiej wolności. Ponadto podnoszą one i podkreślają rozdźwięk, pomiędzy ładem w człowieku a ładem w społeczeństwie, dyskredytując zbieżność zakazów, fundujących ład społeczny i tożsamość człowieka. Tym samym podkreślają napięcie powstające między wolnością człowieka, a interdyktami narzucanymi przez społeczność, negując wszelkie podstawy ładu wspólnotowego.

Tradycyjny język wiary, czy może raczej zawierzenia, jak przekonuje autor The Triumph of the Therapeutic, stracil już swoją moc oddziaływania. Tym samym zachwianiu uległ też system zakazów kulturowych, zaś system zwolnień od tych zakazów nie wystarcza, by integrować jednostki w ich wspólnotowych celach $^{11}$. Wobec tego sens straciło większość pojęć konstytuujących wertykalny charakter każdej kultury.

Rozpowszechnienie postaw terapeutycznych i uznanie ich za normę to negacja tradycyjnych autorytetów w sferze życia zbiorowego, w tym także głęboka przemiana charakteru sprawowania władzy politycznej.

Freudowskie skierowanie refleksji społecznej ku wnętrzu człowieka to w dziedzinie rozważań polityki zwrot ku psychologii politycznej. Na jej gruncie utrwalone zostaje przekonanie, że każda tradycyjna forma władzy jest formą dominacji, zaś jej tradycyjne zadania łączą się nieodmiennie

9 P. Rieff, The Triumph..., s. 106.

10 W przypadku samego Freuda w jego dziełach, jak przekonuje Rieff, dominowało silne nastawienie analityczne, a nie zapędy kulturotwórcze, pomimo że jego analiza krytyczna za swój przedmiot obrała właśnie kulturę, a nie porządek społeczny. Niemniej jednak to właśnie Freud położył podwaliny pod sukces postawy terapeutycznej.

$11 \quad$ P. Rieff, The Triumph..., s. 237. 
z nieakceptowalnym wymiarem kultury opartej na interdyktach społecznych. Władza w sytuacji rozpowszechnienia postaw terapeutycznych nie może więc kwestionować prawa jednostki do wolnej ekspresji jej autentyczności.

Problemem w ramach takiej wizji nie jest docelowa wizja aktywności politycznej, lecz raczej stałe reformowanie zastanych instytucji, nieskończone ustanawianie i kwestionowanie autorytetów, tak by nie pozwolić okrzepnąć władzy zbyt mocno, nie umożliwić jej przerodzenia się w instytucję nadmiernie opresywną. Władza, by nie ograniczać jednostki zbędnymi zakazami, musi być utrzymywana w stanie absolutnej niepewności i słabości. Powinna znajdować się w stanie permanentnej reformy, która nie ma wyznaczonego kresu i celu poza samym reformowaniem.

Polityk w ramach hegemonii autonomii jednostki może więc jedynie pielęgnować warunki umożliwiające tej jednostce subiektywnie pojmowane spełnienie. Punkt ciężkości w ramach ustanawiania celów i poszukiwaniu sensu życia politycznego przesunął się $\mathrm{w}$ takim razie nie tylko z poziomu wspólnotowego na jednostkowy, lecz wręcz ku wnętrzu człowieka, ku strukturze jego psyche.

Władza w epoce dominacji nastawienia terapeutycznego straciła więc jakikolwiek sens. Sprawując zadanie, co najwyżej, inercyjnego administrowana nastawionego dodatkowo na łagodzenie niedogodności, wynikających nawet z tego typu bieżącego zarządzania, przyczyniła się do faktu, że polityka - zamiast być dziedziną rządzenia - stała się obszarem zbiorowej terapii jednostek we współczesnych społeczeństwach liberalnych. 